\title{
Right Ventricular Echocardiography in Patients with Schistosomiasis-induced Pulmonary Hypertension
}

\author{
José Sebastião Abreu \\ Universidade Federal do Ceará, Fortaleza, CE - Brazil
}

This relevant article "Right Ventricular Echocardiography in Patients with Schistosomiasis-induced Pulmonary Hypertension"1 ${ }^{\prime 1}$ stresses the importance of this disease in our community. The study was conducted at Pronto-Socorro Cardiológico de Pernambuco (Procape - UPE) and found that in this valuable contribution of the authors, the first author, Dr. José Maria Del Castillo, is distinguished by his outstanding performance in echocardiography. Dr. Castillo is one of the pioneers in the use, dissemination and education of both conventional echocardiography and new echocardiographic technologies and, in the context of this article, he presents special interest in cardiac strain. ${ }^{2,3}$ All these facts resulted in important information in the study of a serious and determining pulmonary hypertension disease.

Schistosomiasis is one of the most prevalent infectious diseases in the world and is endemic in more than 70 countries. It is estimated that more than 200 million people are affected. ${ }^{4}$ Also note that pulmonary arterial hypertension (PAH) associated with schistosomiasis is potentially the main cause of $\mathrm{PAH}$, so its variable prevalence has achieved up to $25 \%{ }^{5-8}$

In chronic conditions of pressure overload, the right ventricle (RV) can act as a systemic ventricle and even decompensate, resulting in systolic dysfunction and myocardial deformity. The longitudinal function in reduced systemic RV may reflect global ventricular dysfunction. However, reduced longitudinal shortening describes one aspect of myocardial strain, which also occurs in patients without heart failure. This suggests the possibility of increasing compensatory function in another dimension due to changed load conditions..$^{9,10}$

In this study, recommended techniques were performed to evaluate RV. It should be noted, however, that according to the guidelines, RV evaluation through strain is reserved for specific clinical conditions and research in laboratories with extensive experience, ${ }^{11}$ which are the conditions covered by this study.

The purpose of this study was evaluating patients with schistosomiasis mansoni and precapillary PAH, considering the RV systolic function, its contractile mechanics through

\section{Keywords}

Schistosomiasis mansoni; Echocardiography; Hypertension, Pulmonary; Ventricular Dysfunction, Right.

Corresponding author: José Sebastião de Abreu •

Rua Dr. José Lourenço, 500, apto. 700. Postal Code 60115-280, Meireles, Fortaleza, CE - Brazil

E-mail: Jsabreu@cardiol.br/jsabreu10@yahoo.com.br

DOI: $10.5935 / 2318-8219.20160020$ longitudinal and transverse strain, trying to establish myocardial strain patterns associated with RV pressure overload.

Healthy control patients and HAP, variation of RV areas, tricuspid annular plane systolic excursion (TAPSE), tricuspid regurgitation gradient, longitudinal and transverse RV strain were evaluated. The results were compared with clinical and hemodynamic tests.

The result of the comparison between the groups showed that the variation of areas ( $28 \%$ vs. $46 \%$; p $=0.0001)$ and TAPSE (1.9 cm vs. $2.2 \mathrm{~cm} ; \mathrm{p}=0.02)$ were lower in the group with $\mathrm{PHA}$, while the tricuspid regurgitation gradient was higher (76 mmHg vs. $28 \mathrm{mmHg} ; \mathrm{p}=0.0001$ ). As to the strain, it was found that in the group with $\mathrm{PAH}, \mathrm{RV}$ sidewall longitudinal strain was smaller $(-22 \%$ vs. $-37 \%$; $p=0.0001)$, while there was a greater transverse deformation (39\% vs. $21 \% ; p=0.001$ ), showing the deleterious effect on the RV of patients with $\mathrm{PAH}$. These data demonstrate that conventional techniques and new echocardiographic technologies have converging results and add useful information in this disease.

The authors also investigated the association of these parameters with the functional classes within each group, noting, for example, the significant association between variations of areas and longitudinal RV strain, which may be considered for follow-up. This is corroborated by two studies evaluating the prognosis of patients with $\mathrm{PAH}$ using longitudinal strain; however, in these studies, various etiologies were associated with $\mathrm{PAH} .{ }^{12,13}$

Among the various information of this study, the most unusual one reports an increase in RV transverse strain among patients with PAH. According to the authors, an increase in transverse strain can be attributed to $\mathrm{RV}$ remodeling, mainly due to hypertrophy of circular myocardial fibers deriving from the basal band. This type of fiber would be necessary to maintain right ventricular ejection against progressive increase in pulmonary resistance. Although hypertrophy of the circular myocardial fibers suggest an adaptation to systemic RV overload, ventricular torsion did not take place. ${ }^{1}$ This systemic RV characteristic is similar to that reported by Pettersen et al. ${ }^{9}$ in patients with transposition of great vessels after surgery.

Limitations inherent in the technique used are mentioned by the authors, such as low quality images, as they do not allow the correct analysis of strain and make it difficult to see the RV and the amount of segments that can be analyzed.

I congratulate the authors and I am very pleased to express some views about a hard work whose goals have been achieved, which shows to the scientific community that the conventional techniques and the new technologies add information with great potential to be appreciated and replicated in the context of diagnostic and prognostic evaluation. 


\section{References}

1. Del Castillo JM, Bandeira AMP, Albuquerque ES, Lamprea DP, Silveira CAM. Estudo Ecocardiográfico do Ventrículo Direito em Pacientes com Hipertensão Pulmonar por Esquistossomose Mansoni. Arq Bras Cardiol: Imagem cardiovasc. 2016;29(3):84-91

2. Del Castillo JM, Herszkowicz N, Boschilia T, Capuano RL, Cortese MD. Deformação miocárdica tangencial (shear strain) em indivíduos normais: o seu significado. Rev Bras Ecocardiogr Imagem Cardiovasc. 2009;22(4):20-6.

3. Del Castillo JM. Strain cardíaco. Rio de Janeiro: Revinter; 2013.

4. Schwartz E. Pulmonary schistosomiasis. Clin ChestMed. 2002;23(2):433-43.

5. Rocha RL, Pedroso ERP, Rocha MOC, Lambertucci JR, Greco DB, Ferreira CS. Forma pulmonar crônica da esquistossomose mansoni: avaliação clínico-radiológica. Rev Soc Bras Med Trop. 1990;23(2):83-9.

6. Barbosa MM, Lamounier JA, Oliveira EC, Souza MV, Marques DS, Silva AA Pulmonary hypertension in schistosomiasis mansoni. Trans R Soc Troop Med Hyg. 1996;90(6):663-5

7. Lapa M, Dias B, Jardim C, Feranandes CJ, Dourado PM, Figueiredo M, et al. Cardiopulmonary manifestations of hepatosplenic schistosomiasis. Circulation. 2009;119(11):1518-23.

8. Simonneau G, Gatzoulis MA, Adatia I Celermajer D, Denton C, Smevik B, et al. Updated clinical classification of pulmonary hypertension. J Am Coll Cardiol. 2013;62(25 Suppl):D34-D41.
9. Pettersen $\mathrm{E}$, Helle-Valle $\mathrm{T}$, Edvardsen $\mathrm{T}$, Lindberg $\mathrm{H}$, Smith $\mathrm{H}$, Smevik B, et al. Contraction pattern of the systemic right ventricle: shift from longitudinal to circumferential shortening and absent global ventricular torsion. J Am Coll Cardiol. 2007;49(25):2450-6.

10. Tazar J, Haurigot MdP, Caram R, Haurigot GE. Función sistólica del ventrículo derecho en pacientes con hipertensión pulmonar: análisis con strain y strain rate. Insuf card. 2012;7(3):109-16.

11. Rudski LG, Lai WW, Afilalo J, Hua L, Handschumacher MD, Chandrasekaran K, et al. Guidelines for the echocardiographic assessment of the right heart in adults: a report from the American Society of Echocardiography: endorsed by the European Association of Echocardiography, a registered branch of the European Society of Cardiology, and the Canadian Society of Echocardiography. J Am Soc Echocardiogr. 2010; 23(7):685-713.

12. Haeck ML, Scherptong RW, Marsan NA, Homan ER, Schalij MJ, Bax JJ, et al. Prognostic value of right ventricular longitudinal peak systolic strain in patients with pulmonary hypertension. Circ Cardiovasc Imaging. $2012 ; 5(5): 628-36$

13. Hardegree EL, Sachdev A, Villarraga HR, Frantz RP, Mc Goon MD Kushwaha SS. Role of serial quantitative assessment of right ventricular function by strain in pulmonary arterial hypertension. Am J Cardiol 2013;111(1):143-8. 